\title{
Effect of Different Bio Fertilizers on Growth and Yield of Canola (Brassica napus L) var RGS 003
}

\author{
Mehdi Dahmardeh ${ }^{1}$ \\ ${ }^{1}$ Department of Agronomy, University of Zabol, Iran \\ Correspondence: Mehdi Dahmardeh, Department of Agronomy, University of Zabol, Iran. E-mail: \\ dahmard@yahoo.com
}

Received: June 22, 2013 Accepted: July 20, 2013 Online Published: August 15, 2013

doi:10.5539/jas.v5n9p143 URL: http://dx.doi.org/10.5539/jas.v5n9p143

\begin{abstract}
Bio fertilizers effects were studied on growth and yield of canola in Sistan and Balochistan province. An experiment was conducted in a randomized complete block design with three replications. Treatments included bio-fertilizers at eight levels (not inoculation, phosphate bio-fertilizer (barvar2), Nitro Kara, Bio sulfur, phosphate bio-fertilizer (barvar2) +Nitro Kara, Nitro Kara+ Bio sulfur, phosphate bio-fertilizer (barvar2) + Bio sulfur and phosphate bio-fertilizer (barvar2) + Nitro Kara + Bio sulfur). The results showed that bio fertilizers had no significant effect on the seed number per siliques, number of siliques per plant, seed yield, 1000 seed weight, biological yield, seed of sodium and Plant height but significant different on seed of potassium. The combined use of bio fertilizers also was statistically superior to not inoculation treatment. However, the highest yield was got from Nitro Kara + Bio sulfur but no significant different with other treatments. It seems using of inoculation of Nitro Kara + Bio sulfur produced suitable yield compared to not inoculation (31\% greater).
\end{abstract}

Keywords: phosphate bio fertilizer (Barvar 2), nitro kara, bio sulfur

\section{Introduction}

Canola is a member of the Brassicaceae family and has become one of the most important sources of vegetable oil in the world. Its oil also has potentially developed in the bio-diesel market. In addition to oil production, the leaves and stems of canola provide high quality fodder.

Matter because of their low fiber and high protein content (Wiedenhoeft \& Bharton, 1994). Canola grows well in dry environment condition and can tolerate moderately saline soil conditions (Stricker et al., 1997). Canola (Brassica napus L.) is one of the main oil crops in many countries especially in Canada, European Union and USA. Intensive use of chemical fertilizers and other chemicals has produced environmental problems and increased production costs. There centesimo crisis and environmental problems has raised interest in environmental friendly sustainable agricultural practices, which can reduce input costs (Salantur et al., 2005). Canola is nitrogen demanding crop plant. Nitrogen plays vital role in its healthy growth and is one of the main precursors of protein which absorbs in the form of mineral, ammonium or nitrate by canola plant (Hopkins \& Hunter, 2004). The seed yield, total dry matter and harvest index in some genotypes of Brassica napus has been found to improve with higher rates of N (Kopsell et al., 2004). N2-fixing maybe important for plant nutrition by increasing N uptake by the plants and playing significant role as plant growth promoting rhizobacteria (PGPR) in the bio fertilization of crops. Plant growth-promoting rhizohacteria (PGPR) are able exit beneficial upon plant growth. Nitrogen fixation and P. Solubilization (Zaidi et al., 2006) production of antibiotic (Zahir et al., 2004) and increased rood day weight are the principal mechanism for the PGPR. A number of different bacteria promote plant growth, including Azotobacter sp, Azospirillum sp., Pseudomones sp. Bacillus Azotobacter sp (Turan, 2006). Significant and positive effect on plant height and yield of Brassica plant after using Azotobacter was recorded by Gupta and Samnotra (2004). The aim of this study was directed to investigate the effect of Bio fertilizers on the productivity of canola in sistan region.

\section{Materials and Methods}

This experiment was carried out in order to investigate effect of different bio fertilizers on yield of canola plants in Sistan and Balochistan province, Iran. The experimental design was randomized completely block design in three replications in Researches Station of university of Zabol during 2013, where the latitude The field experiment was 
carried out on the University of Zabol farm, Iran $\left(61^{\circ} 41^{\prime} \mathrm{E}, 30^{\circ} 54^{\prime} \mathrm{N}\right.$, above sea level $\left.483 \mathrm{~m}\right)$, Average 30 years rainfall was $49 \mathrm{~mm}$. The experimental soil was sandy-loam texture with $\mathrm{pH}$ of 8.1. Each replication of this design consisted of 8 treatments. And a total of 24 plots were analyzed. The factors examined were eight levels of bio fertilizers (Control, phosphate biological fertilizer (Barvar-2), Nitro Kara, Bio sulfur, phosphate biological fertilizer (Barvar-2) + Nitro Kara, Nitro Kara +Bio sulfur, phosphate biological fertilizer (Barvar-2) + Bio sulfur and phosphate biological fertilizer (Barvar-2) + Nitro Kara+ Bio sulfur). Nitro Kara is Nitrogen fixing bio fertilizer. Nitro Kara has highly efficient nitrogen fixing bacteria of Azorhizobium caulinodans which was isolated from the nature. Bio sulfur is hydrophilic by nature and has a fine particle size, making it very attractive for use in liquid fertilizers or fungicides. Extensive field testing has shown that the effectiveness is far superior to what can be achieved by alternatives based on chemical sulfur. Phosphorus is one of the most important nutrients for plants. The concentration of this element is between 400 to $1000 \mathrm{ppm}$ in cultivated soils. However, because of immobilization by mineral ions such as $\mathrm{Fe}, \mathrm{Al}$ and $\mathrm{Ca}$ or organic acids, the rate of available phosphate $(\mathrm{Pi})$ is well below plant needs. Chemical Pi fertilizer is also immobilized in the soil immediately such that less than 20 percent of add fertilizer is absorbed by crop plants. Barvar-2 is a phosphate Bio fertilizer designed for all agricultural purpose, all types of crops and trees that reduce the need for phosphate chemical fertilizer for at least 50 percent. The area of each plot was $6 \times 1.2 \mathrm{~m}$. The dosage of Bio sulfur was $50 \mathrm{mg}$ per 100 grams of seed for phosphate biological fertilizer (Barvar-2) 5 grams and for Nitro Kara 7 grams. There was a $1 \mathrm{~m}$ distance between two adjacent plots. There was a $30 \mathrm{~cm}$ distance between two adjacent. There were 8 plots in each block and the treatments were allocated randomly to each plot. The cultivar of canola was RGS 003. Determinate traits includes seed number per silique, number of siliques per plant, 1000seed weight, seed yield, biological yield, Harvest index, sodium and potassium of seed. Grain of sodium and potassium measurements were performed using flame photometer, model 360. Statically analysis was conducted using SAS software. Mean comparison was also conducted with Duncan's Multiple Range Test (LSR).

\section{Results and Discussion}

Results obtained from analysis variance indicated that there are no significant difference between biofertilizer expects seed Potassium (Table 1).

Table 1. Analysis of variance for quantitative and qualitative parameters of canola

\begin{tabular}{clllccccccc}
\hline \multicolumn{10}{c}{ Means of Square } \\
\hline S.OV & df & PH & W1000S & SSN & NSP & EY & BY & HI & K & Na \\
\hline Replication & 2 & $141.4^{*}$ & $0.77^{*}$ & 15.04 & 39341.6 & 26711.7 & 857424.2 & 22.00 & 23.89 & 0.93 \\
Bio fertilizer & 7 & $51.26^{\text {ns }}$ & $0.132^{\text {ns }}$ & $8.61^{\text {ns }}$ & $12651.4^{\text {ns }}$ & $7698.02^{\text {ns }}$ & $680294.8^{\text {ns }}$ & $2.91^{\text {ns }}$ & $2.94^{*}$ & 0.07 \\
Error & 14 & 28.75 & 0.139 & 12.04 & 5959.00 & 10506.6 & 1544887.9 & 4.75 & 1.10 & 0.08 \\
\hline C.V (\%) & - & 5.64 & 9.68 & 17.38 & 27.31 & 23.33 & 27.89 & 21.56 & 5.99 & 14.14 \\
\hline
\end{tabular}

significant at $\mathrm{p}<0.05$.

PH: Plant Height, 1000SW:1000 seed weight, SSN: seed silique number, NSP: number of silique with plant, EY: economical Yield, BY: Biological Yield, HI: harvest index, K: seed potassium, Na: seed sodium.

Plant height in inoculation with each of the bacteria compared to non inoculation treatment was no significantly different. Maximum height belonged to inoculation treatments with application of Nitro kara bio fertilizer (98.3 $\mathrm{cm}$ ) (Table 2). The lowest of height was observed in not inoculation $(85.3 \mathrm{~cm})$ and the highest was obtained in Nitro Kara (Table 2) but no significant with phosphate biological fertilizer (Barvar-2) $(96.9 \mathrm{~cm})$. Bio-fertilizers increase root uptake through root development (Yosefi et al., 2011). Furthermore, application of bio-fertilizers increases the plant height by promoting the plant growth regulators (Senthil-Kumar et al., 2009). Studies of Ezz et al. (2011) on banana (Musa spp.) showed that the using of phosphorus fertilization and/or effective microorganisms as a bio-fertilizer increased all studied vegetative growth characters including plant height. Singh et al. (2008) revealed the positive effect of bio-fertilizer on the plant height of Calendula officinalis L. Similar observations have been reported by Chandrikapure et al. (1999) in marigold. Abou El-Yazeid and Abou-Aly (2011) showed the positive effect of phosphate solubilizing microorganisms on the most plant growth parameters of tomato. The effect of phosphate solubilizing bacteria on growth may be due to the activity of phosphate solubilization caused by the strain and increased further mineral availability uptake. The highest 1000 -seed weight 
belongs to Nitro Kara + bio sulfur (Table 2). From the data presented (Tables 2), it seems that Bio fertilizers had the highest effect on the 1000-seed weight. Organic manure accelerates assimilation rate and enhances movement of photo synthates from flag leaf to spike but shorten the grain filling duration. Organic manure plays a very vital role in the process of grain filling, increase leaf area of the crop and may result in increased dry matter production by intercepting more sun light (Wu et al., 2005). The trait of 1000 seed weight also increased due to inoculating seed with studied bacteria in compared with non inoculation. Bio fertilizers improved photosynthesis maybe by increasing water and nutrients absorption leading to produce more assimilate and improve plant growth and thus, 1000 seed weight increased in compared with non inoculation treatment. Hamidi et al. (2007) reported that 1000 grain weight increased by multiple inoculations compared to single inoculation. Maximum seed silique number per plant (21.6) was obtained by Nitro Kara + Bio sulfur fertilizer (Table 2). The increase with Nitro Kara + Bio sulfur may be due to higher number of siliqua and bolder seeds as a result of availability of major and minor nutrients at all the essential stages of growth and development. According to Edwards et al. (2004) vermi-compost can have significant effects on plants germination, growth, flowering, fruiting and yields. Seed number per siliques influenced by bio fertilizer treatments (Table 2). The lowest seed number per siliques belonged to non inoculation treatment. Bio fertilizers caused to increasing seed number per siliques; all kinds of bio fertilizers had same effects on this trait. Maximum Number of silique per plant (385) was obtained by Nitro Kara + Bio sulfur fertilizer (Table 2). Results demonstrated that the different of bio fertilizer application had positive effect on most characters aerial parts. Inoculation of foliage plant with bio-fertilizers had maximum effect on yield. Moreover, the effect of different on most characters was no significant (Tables 1). Overall results showed that bio fertilizer application is effective on quantity traits of Brassica napus L., whether alone or without bio fertilizer. The highest economical and biological yield belongs to Nitro Kara + bio sulfur (Table 2). From the data presented (Tables 2), it seems that Bio fertilizers had the highest effect on economical and biological yield compared to without bio fertilizer. Mubassara et al. (2008) had shown that Bio-fertilizers have improved quantity and quality features of wheat. In general Nitro kara followed can increase by positive influence on macro elements absorption such as N, P and $\mathrm{K}$ (Narula et al., 2000), micro elements such as Zn and Fe (Wani et al., 1988), improving water distributing in plant, developing Nitrate Redoctaz activity and finally producing plant hormones which have an important role in plant growth. These results are agreed with Singh et al. (2004) who believed to maximize production of different wheat cultivars which inoculated with Azotobacter under normal conditions. Results obtained from this study showed that with using bio fertilizer inoculation methods, seed yield can be improved. Analysis of variance showed that the effect of various kinds of bio-fertilizer application on the content of Potassium was significant at 5\% probability level (Table 1). The effect of bio-fertilizers application on the content of sodium at $5 \%$ probability level was not significant (Table 1). The results related to the content of Potassium revealed that highest $(19.3 \mathrm{mg} / \mathrm{kg})$ at Bio sulfur fertilizer and lowest $(16.3 \mathrm{mg} / \mathrm{kg})$ content were obtained in no inoculation with bio-fertilizer, respectively (Table 2). The results were shown that in the between of bio fertilizers maximum of potassium and sodium of seed related to Bio sulfur.

Table 2. Means of quantities characteristics of Canola as influenced by Bio fertilizers

\begin{tabular}{llllllllll}
\hline Treatment & PH $(\mathrm{cm})$ & $1000 \mathrm{sw}(\mathrm{g})$ & $\mathrm{SSN}$ & $\mathrm{NSP}$ & $\mathrm{EY}(\mathrm{kg} / \mathrm{h})$ & $\mathrm{BY}(\mathrm{kg} / \mathrm{h})$ & $\mathrm{HI}$ & $\mathrm{K}(\mathrm{mg} / \mathrm{kg})$ & $\mathrm{Na}(\mathrm{mg} / \mathrm{kg})$ \\
\hline Control & $85.3 \mathrm{~b}$ & $3.5 \mathrm{a}$ & $17.3 \mathrm{a}$ & $201 \mathrm{~b}$ & $379.1 \mathrm{a}$ & $3928 \mathrm{a}$ & $9.6 \mathrm{a}$ & $16.3 \mathrm{c}$ & $1.8 \mathrm{a}$ \\
PBFB2 $^{*}$ & $96.9 \mathrm{a}$ & $4.0 \mathrm{a}$ & $21.3 \mathrm{a}$ & $221 \mathrm{~b}$ & $500.0 \mathrm{a}$ & $4817 \mathrm{a}$ & $11.2 \mathrm{a}$ & $17.0 \mathrm{bc}$ & $2.0 \mathrm{a}$ \\
Nitro Kara & $98.3 \mathrm{a}$ & $3.7 \mathrm{a}$ & $18.3 \mathrm{a}$ & $230.6 \mathrm{~b}$ & $380.5 \mathrm{a}$ & $4833 \mathrm{a}$ & $8.8 \mathrm{a}$ & $16.9 \mathrm{bc}$ & $2.1 \mathrm{a}$ \\
Bio sulfur & $94.6 \mathrm{ab}$ & $3.8 \mathrm{a}$ & $21.0 \mathrm{a}$ & $335.6 \mathrm{ab}$ & $432.7 \mathrm{a}$ & $4094 \mathrm{a}$ & $10.5 \mathrm{a}$ & $19.3 \mathrm{a}$ & $2.3 \mathrm{a}$ \\
PBFB2+ Nitro Kara & $98.0 \mathrm{a}$ & $3.7 \mathrm{a}$ & $21.3 \mathrm{a}$ & $299.3 \mathrm{~b}$ & $483.3 \mathrm{a}$ & $4122 \mathrm{a}$ & $10.5 \mathrm{a}$ & $17.5 \mathrm{abc}$ & $2.1 \mathrm{a}$ \\
PBFB2+ Bio sulfur & $95.3 \mathrm{ab}$ & $3.6 \mathrm{a}$ & $18.3 \mathrm{a}$ & $258.6 \mathrm{ab}$ & $438.8 \mathrm{a}$ & $4421 \mathrm{a}$ & $11.0 \mathrm{a}$ & $17.8 \mathrm{abc}$ & $2.0 \mathrm{a}$ \\
Nitro Kara + Bio sulfur & $95.0 \mathrm{ab}$ & $4.1 \mathrm{a}$ & $21.6 \mathrm{a}$ & $385.0 \mathrm{a}$ & $500.0 \mathrm{a}$ & $5289 \mathrm{a}$ & $12.0 \mathrm{a}$ & $16.9 \mathrm{bc}$ & $2.1 \mathrm{a}$ \\
PBFB2+ Bio sulfur + Nitro Kara & $96.2 \mathrm{a}$ & $4.0 \mathrm{a}$ & $20.3 \mathrm{a}$ & $329.6 \mathrm{ab}$ & $400.0 \mathrm{a}$ & $4142 \mathrm{a}$ & $7.5 \mathrm{a}$ & $18.5 \mathrm{ab}$ & $2.0 \mathrm{a}$ \\
\hline LSD 5\% & 9.39 & 0.65 & 6.07 & 135.2 & 179.5 & 2177 & 3.8 & 1.84 & 0.52 \\
\hline
\end{tabular}

*PBFB2: phosphate biological fertilizer (Barvar-2).

Any two means not sharing a common letter differ significantly from each other at $5 \%$ probability.

\section{Conclusion}

In general, using bio fertilizers and manage integrated nourishment quantitatively and qualitatively is one of the efficient ways to improve plants production and environment would have a better condition if chemical fertilizers 
consumption reduce. The combined use of bio fertilizers also was statistically superior to other treatments. In this experiment, inoculation of canola seed with PGPRs showed significant effects on yield and other studied traits. The highest yield was got from inoculation of Nitro Kara and Bio sulfur produced suitable yield. It seems that can be saving to fertilizer by application of bio fertilizers combined chemical fertilizers. Those using bio fertilizers also improving soil physiological structure and also increase organic matters content and nitrogen available to coexistent plant. Totally, the obtained results revealed that using bio-fertilizer combined significantly improved the quantity and quality characters compared to control.

\section{Acknowledgments}

The authors gratefully acknowledge the help and financial support of Research Center of University of Zabol and agronomy students Mr Porya Dostaki, M. Jafari and Miss.SH. Mdady, N. Fryabi and M. Balouchi.

\section{References}

Abou El-yazeid, A., \& Abou-Aly, H. E. (2011). Enhancing growth, productivity and quality of tomato plants using phosphate solubilizing microorganisms. Aust J Basic Appl Sci., 5(7), 371-379.

Chandrikapure, K. R., Sadavarte, K. T., Panchbhai, D. M., \& Shelk, B. D. (1999). Effect of bio-inoculants and graded dose of nitrogen on growth and flower yield of marigold (Tagetes erecta L.). The Oris J Hort., 21(2), 31-34.

Edwards, C. A., Dominguez, J., \& Arancon, N. Q. (2004). The influence of vermi composts on plant growth and pest incidence. In Zoology for Sustainable Development in the 21st century (pp. 12-24).

Ezz, T. M., Aly, M. A., Saad, M. M., \& El-Shaieb, F. (2011). Comparative study between bio- and phosphorus fertilization on growth, yield, and fruit quality of banana (Musa spp.) grown on sandy soil. J Saudi Soc Agric Sci (In Press).

Gupta, A. K., \& Samnotra, R. K. (2004). Effect of bio fertilizers and nitrogen on growth, quality and yield of cabbage (Brassica napus). Environ. Ecol., 22, 551-553.

Hamidi, A., Asgharzadeh, A., Choukan, R., Dehghan Shoar, M., Ghalavand, A., \& Malakouti, M. J. (2007). Study on plant growth promoting rhizobacteria (PGPR) biofertilizers application in maize (Zea mays L.) cultivation by adequate input. Environmental Sciences, 4(4), 1-19.

Hopkins, W. G., \& Hunter, N. P. A. (2004). Introduction to Plant Physiology (3rd ed., p. 576). New York: John Wiley and Sons Inc.

Kopsell, D. E., Kopsell, D. A., Lefsrud, M. G., \& Curran-Celentano, J. (2004). Variability in elemental accumulations among leafy Brassica oleracea cultivars and selections. J. Plant Nutr., 27, 1813-1826. http://dx.doi.org/10.1081/PLN-200026431

Mubassara, S., Zahed, U. M., Motiur, R. M., Patwary, F. K., \& Akond, M. A. (2008). Seed inoculation effect of Azospirillum spp. On growth, biomass and yield parameter of wheat. Acad J Plant Sci, 1(4), 56-61.

Narula, N., Kumar, V., Behi, R., Deubel, A., Gransee, A., \& Merbach, W. (2000). Effect of p-solubilizing (Azotobacter chroococcum) on N,P,K uptake in pr- responsive wheat genotypes grown under greenhouse

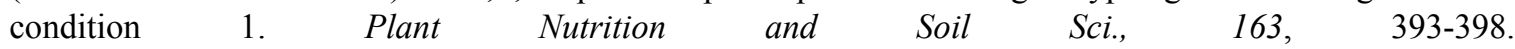
http://dx.doi.org/10.1002/1522-2624(200008)163:4<393::AID-JPLN393>3.0.CO;2-W

Salantur, A., Ozturk, A., Akten, S., Sahin, F., \& Donmez, F. (2005). Effect of inoculation with non-indigenous and indigenous rhizobacteria of Erzurum (Turkey) origin on growth and yield of spring barley. Plant and Soil, 275, 147-156. http://dx.doi.org/10.1007/s11104-005-8094-z

Senthil-Kumar, T., Swaminathan, V., \& Kumar, S. (2009). Influence of nitrogen, phosphorus and bio-fertilizer on growth, yield and essential oil constituents in Raton crop (Artemisia pallens). Electron J Environ Agric Food Chem, 8(2), 86-95.

Singh, R., Behi, R. K., Singh, K. P., Lain, P., \& Namla, N. (2004). Performance and gene effects for wheat yield under inoculation of arbuscular mycorrhiza fungi and Azotobacter chroococcum. Haiyana Agricultural University. Hisar, India. Plant Soil Environ., 50, 409.

Singh, Y. P., Dwivedi, R., \& Dwivedi, S. V. (2008). Effect of biofertilizers and graded dose of nitrogen on growth and flower yield of calendula (Callendula officinalis). Plant Arch, 8(2), 957-958.

Stricker, J. A., Prine, J. A., \& Riddle, T. C. (1997). Yield of kenaf grown on two soils at two locations in Florida, Soil Crop Sci. Soc. Florida Proc., 56, 35-37. 
Turan, M., Ataoglu, N., \& Sahin, F. (2006). Evaluation of the capacity of phosphate solubilizing bacteria and fungi on different forms of phosphorus in liquid culture. Sustainable Agricultural, 28, 99-108. http://dx.doi.org/10.1300/J064v28n03_08

Wani, S. P., Chandrapalaiah, S., Zambre, M. A., \& Lee, K. K. (1988). Association between nitrogen-fixing bacteria and pear millet plants, responses mechanisms and resistance. Plant and Soil, 110, $284-302$. http://dx.doi.org/10.1007/BF02226810

Wiedenhoeft, M., \& Bharton, B. A. (1994). Management and environment effects on Brassica Forage quality, Agronomy Journal, 86, 227-237. http://dx.doi.org/10.2134/agronj1994.00021962008600020003x

Wu, S. C., Cao, Z. H., Li, Z. G., Cheung, K. C., \& Wong, M. H. (2005). Effects of biofertilizer containing N-fixer, $\mathrm{P}$ and $\mathrm{K}$ solubilizers and AM fungi on maize growth: a greenhouse trial. Geoderma, 125, $155-166$. http://dx.doi.org/10.1016/j.geoderma.2004.07.003

Yosefi, K., Galavi, M., Ramrodi, M., \& Mousavi, S. M. (2011). Effect of bio-phosphate and chemical phosphorus fertilizer accompanied with micronutrient foliar application on growth, yield and yield components of maize (Single Cross 704). Australian Journal of Crop Science, 5, 175-180.

Zaidi, A., \& Mohammad, S. (2006). Co-inoculation effects of phosphate solubilizing micro-organisms and glomus fasciculatum on green grambrady rhizobium symbiosis. Agricultural Science, 30, 223-230.

Zahir, A. Z., Arshad, M., \& Frankenberger, W. F. (2004). Plant growth promoting rhizobacteria: applications and perspectives in agriculture. Advances in Agronomy, 81, 97-168. http://dx.doi.org/10.1016/S0065-2113(03)81003-9

\section{Copyrights}

Copyright for this article is retained by the author(s), with first publication rights granted to the journal.

This is an open-access article distributed under the terms and conditions of the Creative Commons Attribution license (http://creativecommons.org/licenses/by/3.0/). 